\title{
Planktonic Diatoms Species Composition and Water Characteristics Along Selected Sites of River Kisat, Kisumu County, Kenya
}

Manohar S*, Otieno AA and Kitur EL

Department of Environmental Sciences, Kenyatta University P.O Box 43844-00100, Nairobi, Kenya

\begin{abstract}
In all global aquatic ecosystems, species composition of micro and macro organisms, abundance, growth, development and their distribution depend on quantity of contaminants, types of contamination; levels of chemical concentrations; sediment load; electrical conductivity; turbidity; seasonal variations; depth, width, flow rate, number of inlets and outlets with volume of water and also the impacts of anthropogenic activities always reflect on the water quality of a wetland. Physico-chemical parameters and planktonic diatoms species composition were studied at five selected sampling stations (C1-C5) along River Kisat from March to August 2016. There are 26 species of planktonic diatoms belong to 13 genus which are Amphora, Aulacoseira, Cyclotella, Cymbella, Diatoma, Fragillaria, Gomphocymbella, Navicula, Nitzschia, Pinnularia, Stephomodiscus Surillela and Synedra. Out of these 26 species, only eight species (Cymbella cistula; Cymbella sp; Diatoma hiemiale; Navicula granatum; Nitzschia lucastris; Nitzschia palea; Nitzchia recta and Nitzschia sub-acicularis) are present in all the five sampling stations, while Fragillaria longissima and Gomphocymbella beccari are present only once in sampling station C4 and C5 respectively. Only genus Nitzschia has five species followed by the genus Aulacoseira represented by three species. There are seven genus which are Amphora, Cyclotella, Cymbella, Diatoma, Fragillaria, Navicula and Synedra represented by two species each, while rest of the four genus including Pinnularia, Gomphocymbella, Surillella and Stephomodiscus are represented only with one species each. The mean monthly values of selected physico-chemical parameters are: electrical conductivity 657.27 $\pm 186.78 \mu \mathrm{S} / \mathrm{cm}$, temperature $24.84 \pm 0.65^{\circ} \mathrm{C}, \mathrm{pH} 7.87 \pm 0.24$, dissolved oxygen $4.19 \pm 0.7 \mathrm{mg} / \mathrm{l}$, turbidity $89.90 \pm$ $9.76 \mathrm{NTU}$, flow rate $1.38 \pm 0.05 \mathrm{~km} / \mathrm{h}$; total alkalinity $150.85 \pm 28.23 \mathrm{mg} / \mathrm{l}$, total nitrogen $657.27 \pm 227.56 \mu \mathrm{g} / \mathrm{l}$, total phosphorus $677.18 \pm 20.87 \mu \mathrm{g} / \mathrm{l}$, silicates $4.11 \pm 0.52 \mathrm{mg} / \mathrm{l}$ and chlorophyll-a $130.54 \pm 40.15 \mathrm{mg} / \mathrm{l}$. The study revealed that only $\mathrm{pH}$, dissolved oxygen, alkalinity and silicate show significant difference $(p \leq 0.05)$ along Kisat river but rest of the physico-chemical levels of conductivity, turbidity, total nitrogen, total phosphorus show higher concentrations in river water. It is concluded that the presence or absence of planktonic species and their frequency should be used as bioindicator(s) to assess the status of water quality of any aquatic ecosystem.
\end{abstract}

Keywords: Planktonic diatoms composition; River Kisat; Lake Victoria Basin; Kenya

\section{Introduction}

Planktonic species composition depends on suitable habitats, interaction with surrounding environment, association and competition with other species, depth of water and its flow rate based on climatic variations, nutrient load and their concentrations, water availability and its quality; producer and consumer ratio and impacts of other ecological factors within the riverine ecosystem. Under present situation, due to impacts of anthropogenic activities, human population explosion, deforestation, heavy industrialization, excessive use of agrochemicals, sediment load, water runoff from polluted dump sites; flooding, decomposition of organic matter and discharge of untreated industrial, municipal and household wastes are the main causes to pollute the streams, rivers and lakes in under-developing nations. These polluted water bodies provide habitats for many parasites and unwanted toxic planktonic species and or the representatives of the class Cynophyceae/ Myxophyceae and or Bacillariophyceae.

Diversity of algal species and their high densities indicate warning signs of deteriorating water conditions [1]. Diatoms are useful in indicating specific water quality problems such as organic pollution, eutrophication and heavy metal pollution [2]. All categories of hydrophytes play a significant role in an aquatic ecosystem and their stratification (i) free floating, (ii) attached floating (iii) submerged and (iv) emergent species depends on the interaction of biological, physical, chemical characteristics of water and other environmental variables such as light intensity, duration and quality, temperature fluctuations, intensity of turbulent mixing, benthic feeds and seasonal fluctuations [3].
Species composition or the communities of micro and macrohydrophytes are the best indicators to monitor and assess the water quality of any natural or manmade wetlands. Nutrient enrichment always has its direct impacts on the composition of planktons and aquatic angiosperms which alter the structure and function of any aquatic ecosystem [4]. Phytoplankton which inhibit the upper eutrophic layer are the main causes of high turbidity if density increases [5].

Most water courses flowing through residential areas are vulnerable to pollution and become sinks for some hazardous substances or products that contain harmful elements which are not degradable in the environment and may cause deleterious effects to the health [6-8]. Phytoplankton species are indicative of the effects of specific water quality problems. Changes in water chemistry will inhibit the multiplication of some species [9]. Phytoplankton species depend mainly on the availability of nutrients, light and temperature [10]. Water pollution associated with agricultural systems, industrial, household and municipal wastes, animal dung/manure, nitrates, phosphates and

${ }^{*}$ Corresponding author: Manohar S, Department of Environmental Sciences, Kenyatta University P.O Box 43844-00100, Nairobi, Kenya, Tel: +254738974888; E-mail: prof.dr.smanohar@gmail.com

Received March 16, 2017; Accepted May 09, 2017; Published June 14, 2017

Citation: Manohar S, Otieno AA, Kitur EL (2017) Planktonic Diatoms Species Composition and Water Characteristics Along Selected Sites of River Kisat, Kisumu County, Kenya. J Environ Anal Toxicol 7: 475. doi: 10.4172/2161-0525.1000475

Copyright: () 2017 Manohar S, et al. This is an open-access article distributed under the terms of the Creative Commons Attribution License, which permits unrestricted use, distribution, and reproduction in any medium, provided the original author and source are credited. 
Citation: Manohar S, Otieno AA, Kitur EL (2017) Planktonic Diatoms Species Composition and Water Characteristics Along Selected Sites of River Kisat, Kisumu County, Kenya. J Environ Anal Toxicol 7: 475. doi: 10.4172/2161-0525.1000475

Page 2 of 7

other chemical fertilizers, heavy metals, pathogens and sediment load cause serious ecological ramifications that pass through food chains to humans [11]. Water quality of the lake depends on the growth of planktonic diatoms and level of pollution within fresh water rivers [12].

Algal communities, their growth, taxonomic composition are strongly influenced by water chemistry and respond predictably and sensitively to nutrient enrichment, organic contamination, pesticides, changes in $\mathrm{pH}$ and conductivity [13]. There is strong link between nutrient availability and diatom community structure and also mentioned that the community variation depends directly on the nutrient presence $[14,15]$. There is strong correlation between $\mathrm{pH}$, dissolved oxygen, alkalinity, conductivity, substratum conditions and the structure of the diatom community [16]. High concentrations of heavy metals show negative impacts on the diatom community, causing frustule deformities and loss of their diversity $[17,18]$.

Eutrophication of water is often linked with increased productivity, over simplification of the biotic communities, and a consequent decrease in metabolism of bottom-dwelling species that are unable to cope with the associated increase in nutrient loading [19]. Eutrophication leads to change the community structure, devastating impacts on food web, and alterations in biogeochemical cycles [20,21].

\section{Materials and Methods}

\section{Study area}

Kisumu city is about $500 \mathrm{~km}$ on the Western side from Nairobi, the capital city of Kenya (Figure 1). Research was conducted along River Kisat originates from a small swamp on the Eastern part of Kisumu county situated at an altitude of $1133 \mathrm{~m}$ and lies between Latitudes $0^{\circ}$ $18^{\prime} \mathrm{S}$ to $0^{\circ} 04^{\prime} \mathrm{N}$ and Longitudes $34^{\circ} 43^{\prime} \mathrm{E}$ to $35^{\circ} 30^{\prime} \mathrm{E}$ and drains into Nyanza Gulf of Lake Victoria, Kenya.

The annual average temperature and rainfall were about $24^{\circ} \mathrm{C}$ and $1250 \mathrm{~mm}$ respectively but the wind velocity varies between $16-21 \mathrm{Km} / \mathrm{h}$. Geology of the area is volcanic and soil types are the mixture of sand, clay and loam. Human population of the area is approximately 409,928 people and major socio-economic activities are farming/fishing/labors/ small business. Most of the low income group people stay in Obunga slum or within the poor infrastructure, have no awareness of waste management and even there is no enforcement of environmental laws by county officials, therefore, dumping/discharging/disposal of wastes are common trend within the study area.

\section{Data collection and analysis}

Each sampling station was selected along the river at an interval of about $2 \mathrm{Km}$ from Nyalenda swamp, the origin of river Kisat (Figure 2). Sampling station $\mathrm{C} 1$ is located just after few meters from Nyalenda swamp, C2 is after slum; station C3 is after sewerage treatment plant, station C4 located under the bridge after discharge of industrial and municipal wastes and station $\mathrm{C} 5$ is downstream where river Kisat drops in Lake Victoria. Water samples were collected between 7 am and $10 \mathrm{am}$ while the weather conditions were dry with low erratic precipitation, temperature was between $24^{\circ} \mathrm{C}$ and $25^{\circ} \mathrm{C}$ and the wind velocity was less than $15 \mathrm{Km} / \mathrm{h}$

All the water samples were collected once in a month between $07 \mathrm{am}$ and $10 \mathrm{am}$ from all the five sampling stations along river Kisat during the study period (March to August 2016), to analyze chemical parameters and to study planktonic composition but physical parameters were recorded during the field study. River water temperature, dissolved

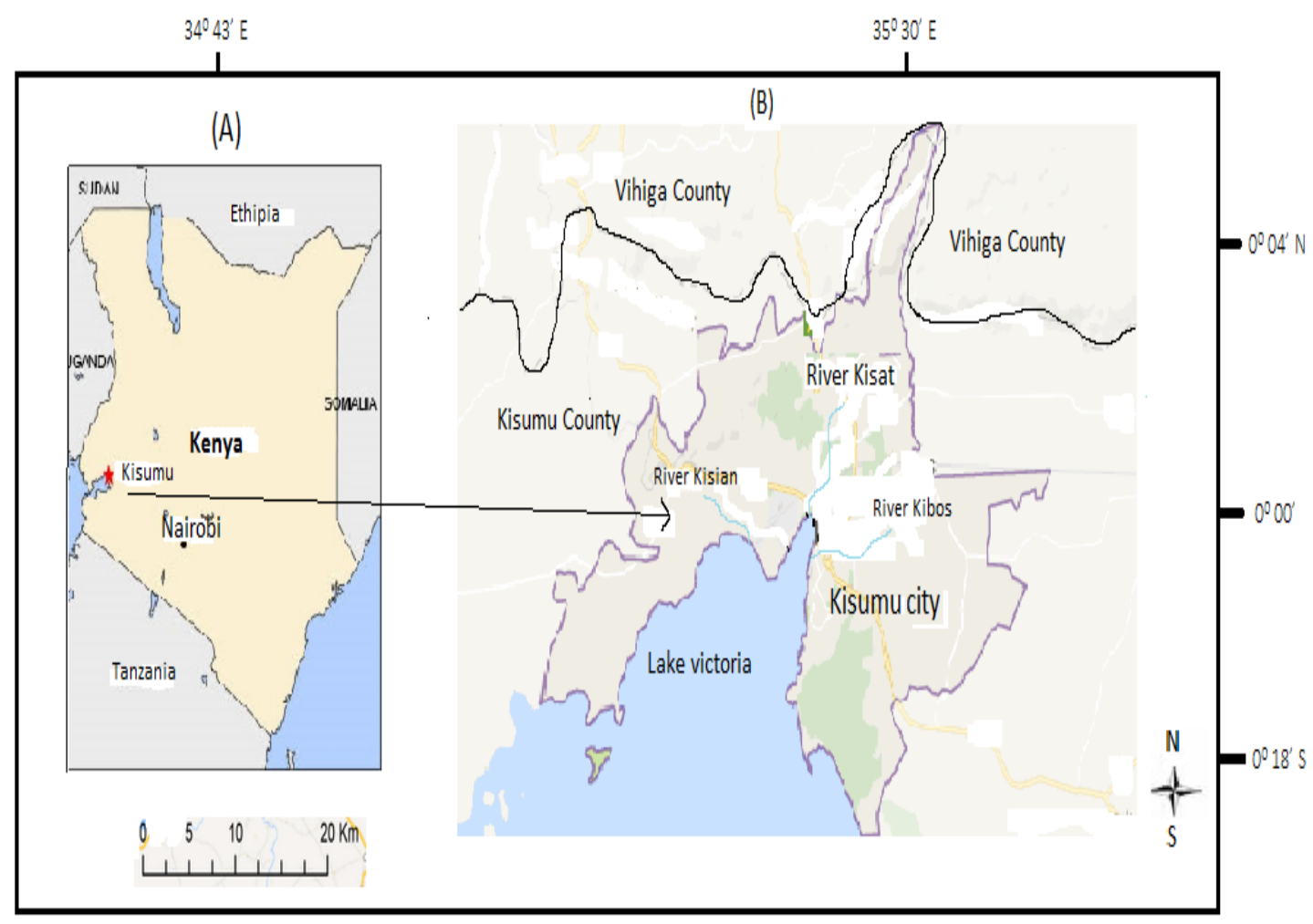

Figure 1: Map of Kenya (A) and detailed map of Kisumu County (B) shows River Kisat (study area) drains in Lake Victoria, Kenya. 
Citation: Manohar S, Otieno AA, Kitur EL (2017) Planktonic Diatoms Species Composition and Water Characteristics Along Selected Sites of River Kisat, Kisumu County, Kenya. J Environ Anal Toxicol 7: 475. doi: 10.4172/2161-0525.1000475

Page 3 of 7

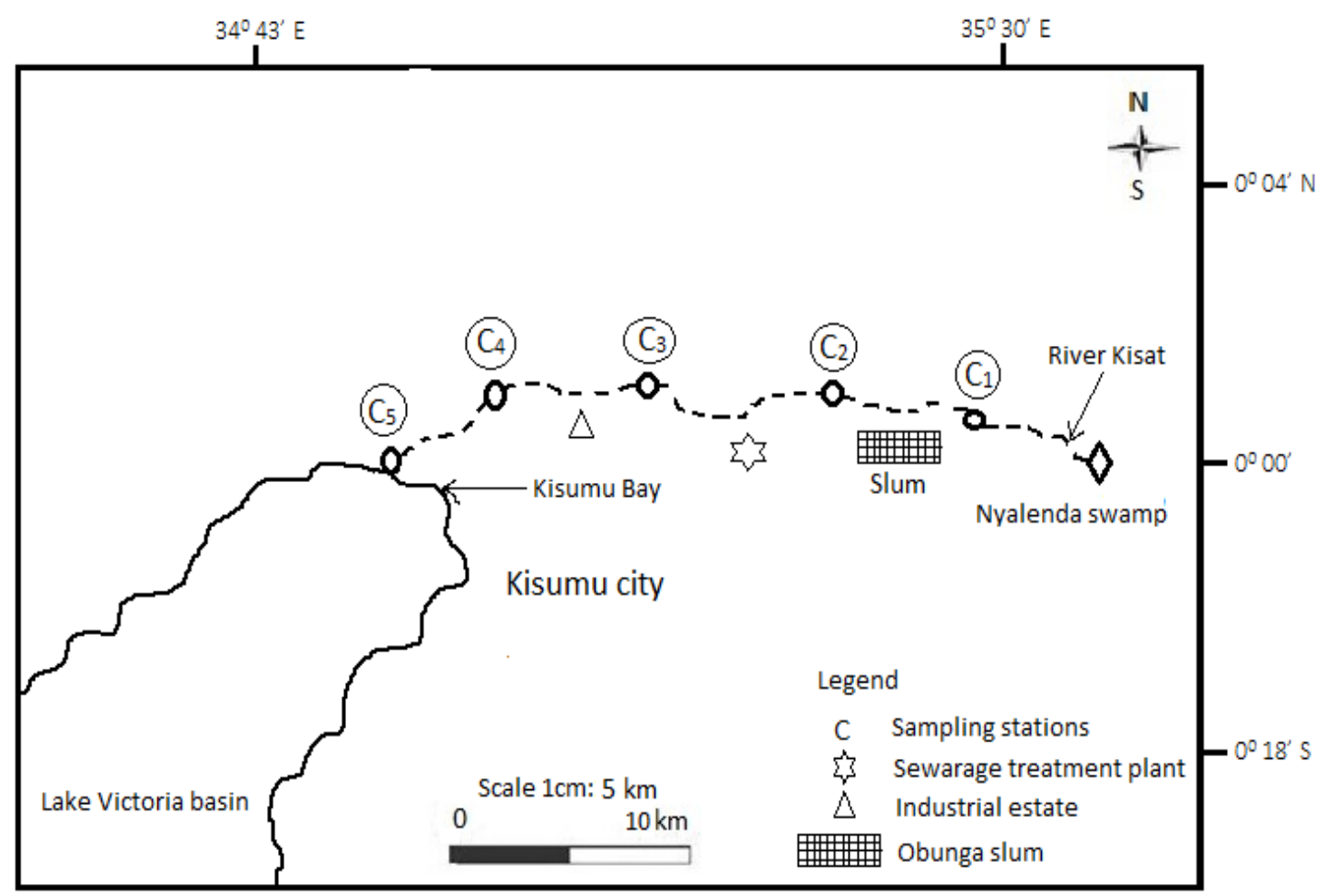

Figure 2: Map of study area shows five selected data sampling stations (C1 to C5) along River Kisat originates from Nyalenda swamp and drops in Kisumu bay, part of Lake Victoria Basin, Kenya.

oxygen, $\mathrm{pH}$, conductivity and turbidity were measured using a portable CX-401 multifunctional data logger and turbidometer. Flow rate of the river water was recorded using current meter. To collect water samples, all plastic sampling bottles of $500 \mathrm{ml}$ were soaked in $10 \% \mathrm{HCl}$, cleaned and rinsed with distilled water. For chemical analysis, water samples were collected by scooping water below the surface at the of depth of $15-30 \mathrm{~cm}$ and fixed with $0.2 \mathrm{M} \mathrm{H}_{2} \mathrm{SO}_{4}$, firmly corked, kept in an ice box at $4^{\circ} \mathrm{C}$ and transported to the laboratory of Kenya Marine and Fisheries Research Institute, Kisumu. All the 30 water samples were collected and analyzed following the standard methods [1]. Total alkalinity was determined by titration method; total phosphorus, total nitrogen and silicates were analyzed by Calometric method using UV/ VIS spectroscopy machine T80+ [1]. Chlorophyll-a was extracted by using $90 \%$ acetone [19].

To study the composition of planktonic diatoms, water samples were collected from 7 am-10 am from all five sampling stations (C1 to C5) by scooping water at a depth of $15-30 \mathrm{~cm}$ below the water surface and filtered through a plankton net with pore size of $64 \mu \mathrm{m}$, transferred into $100 \mathrm{ml}$ glass bottles and fixed with acidic Lugol's Iodine solution before transporting for identification and analysis. Planktonic diatoms composition was determined microscopically. One drop of water or $0.2 \mathrm{ml}$ water sample was placed in an Utermohl sampling chamber and kept at least for three hours to get settled [1]. Species were studied using a Zeiss Axioinvert 35 inverted microscope at $40 \mathrm{X}$ magnification, identified and confirmed with proper taxonomic keys [22,23].

\section{Results and Discussion}

\section{Physico-chemical parameters}

Water quality of river Kisat was determined by measuring the temperature ${ }^{\circ} \mathrm{C}$, flow rate, $\mathrm{pH}$, dissolved oxygen, conductivity, turbidity and also by analyzing alkalinity, total nitrogen, total phosphate, silicate and chlorophyll-a on monthly basis for six months from March to August 2016 during dry season.

Mean monthly temperature is $25.07 \pm 0.78^{\circ} \mathrm{C}, 24.78 \pm 0.67^{\circ} \mathrm{C}, 24.95$ $\pm 0.71^{\circ} \mathrm{C}, 24.75 \pm 0.54^{\circ} \mathrm{C}$ and $24.63 \pm 0.42^{\circ} \mathrm{C}$ at sampling stations $\mathrm{C} 1$, $\mathrm{C} 2, \mathrm{C} 3, \mathrm{C} 4$ and $\mathrm{C} 5$ respectively but the average temperature is 24.84 $\pm 0.65^{\circ} \mathrm{C}$ (Table 1). ANOVA test revealed that the recorded p-value of temperature at all the sampling stations along the river is not significantly different $(\mathrm{p}=0.441>0.05)$. Water temperature of the river depends on duration, intensity and quality of solar radiation; changes in weather patterns, seasonal and climatic variations; depth, clarity, width and flow rate of river water; presence or absence of suspended organisms; covered or open water surface, humidity and cloud cover within the area.

Flow rate varies at all sampling stations between $1.00 \pm 0.02 \mathrm{~km} / \mathrm{h}$ and $1.7 \pm 0.08 \mathrm{~km} / \mathrm{h}$ (Table 1$)$. The lowest flow rate $(1.00 \pm 0.02 \mathrm{~km} / \mathrm{h})$ is at (C5) sampling station because it is densely covered with excessive growth of free floating aquatic angiosperm Eichhornia crassipes and in addition there are 20 planktonic species suspended on this site in river water. Highest flow rate $(1.7 \pm 0.08 \mathrm{~km} / \mathrm{h})$ is at station C4 due to heavy discharge of effluents into the river from the sewage plant and also from industries. ANOVA test shows no significant difference $(\mathrm{p}=0.358>0.05)$ in flow rate of the river along all sampling stations. Normally, flow rate depends on the gravity, volume of water, number of inlets and outlets, width \& depth; growth, distribution and stratification of hydrophytes within the water body. This Kisat river is a small water body flows on even topography, covers short distance of about $10 \mathrm{~km}$ from the place of origin with width between $0.6 \mathrm{~m}$ at upstream and $4.3 \mathrm{~m}$ at the river 
Citation: Manohar S, Otieno AA, Kitur EL (2017) Planktonic Diatoms Species Composition and Water Characteristics Along Selected Sites of River Kisat, Kisumu County, Kenya. J Environ Anal Toxicol 7: 475. doi: 10.4172/2161-0525.1000475

Page 4 of 7

mouth with maximum depth of $0.4 \mathrm{~m}$ with low water volume during dry study period.

Mean monthly $\mathrm{pH}$ is $6.12 \pm 0.16$ at station $\mathrm{C} 1,7.69 \pm 0.17$ at $\mathrm{C} 2$, $8.97 \pm 0.22$ at $\mathrm{C} 3,8.85 \pm 0.24$ at $\mathrm{C} 4$ and $7.72 \pm 0.24$ at $\mathrm{C} 5$ and overall average of $\mathrm{pH}$ is $7.87 \pm 0.24$ (Table 1). Using ANOVA test, p-value $(\mathrm{p}=0.001 \leq 0.05)$ of river water is significantly different. In water bodies, $\mathrm{pH}$ depends on the quality, quantity and types of discharged chemicals/ wastes; death \& decay of vegetation/plant and animal products; flow rate, volume, depth of water; and its interaction with atmosphere. Based on average $\mathrm{pH}$ value, Kisat river water is alkaline at sampling stations C3 and C4 due to discharge of untreated waste from the slum, sewerage and industries along this water body but at sampling station $\mathrm{C} 1$, the $\mathrm{pH}$ of the water is slightly acidic (6.12 \pm 0.78$)$.

Level of dissolved oxygen is low $(3.42 \pm 0.40 \mathrm{mg} / \mathrm{l})$ at sampling station C5 where river Kisat water drains with all the pollutants into Lake Victoria Basin but from the very beginning at $1^{\text {st }}$ sampling station C1 close to Nyalenda swamp, near the origin of river Kisat even dissolved oxygen level $(5.92 \pm 0.75 \mathrm{mg} / \mathrm{l})$ is less than the recommended International standards. Using ANOVA test, $p$-value $(p=0.001 \leq 0.05)$ of dissolved oxygen in river is significantly different. According to [13] the rate of metabolic activity, diffusion, atmospheric pressure, temperature, flow rate, and proximity to the atmosphere, effects volume of dissolved oxygen in water.

Conductivity of the river water fluctuates between $390.75 \pm 118.40$ $\mu \mathrm{S} / \mathrm{cm}$ and $840.93 \pm 330.32 \mu \mathrm{S} / \mathrm{cm}$. The average values of conductivity are $390.75 \pm 118.40 \mu \mathrm{S} / \mathrm{cm}, 839.65 \pm 323.01 \mu \mathrm{S} / \mathrm{cm} ; 796.45 \pm 253.32 \mu \mathrm{S} / \mathrm{cm}$, $840.93 \pm 330.32 \mu \mathrm{S} / \mathrm{cm}$ and $695.43 \pm 226.15 \mu \mathrm{S} / \mathrm{cm}$ at sampling stations C1, C2, C3, C4 and C5 respectively with an average of $657.27 \pm 186.78$ $\mu \mathrm{S} / \mathrm{cm}$ (Table 1 ). ANOVA test shows that $\mathrm{p}$-values are not significantly different $(p=0.267>0.05)$. Conductivity levels in rivers are influenced by total dissolved chemicals, suspended solids; submerged, attached or floating organisms; growth, density, death and decay of aquatic organisms in water body; sediment load due to run off \& soil erosion from the catchment areas and impacts of human activities. In tropics, rainfall is unpredictable, temperature and wind velocity also fluctuate a lot between day and night. These climatic factors also influence the conductivity of water body due to high rate of evapotranspiration, light penetration, soil erosion \& deposition in water body, depth, flow rate and volume of water; number of inlets and outlets; and also on the topography of the region. Conductivity is highest at sampling station C4 because every day unexpected quantities/volumes of untreated effluents and municipal wastes from fish processing plant, slaughter houses; match box, cotton processing \& detergent industries; erosion of agrochemicals are discharged and in addition to all these, washing of many lorries, containers, tankers are also going on near the catchment of river Kisat.

Turbidity varies between $32.37 \pm 5.15$ NTU and $122.98 \pm 18.97$ NTU at stations C1 and C5 respectively. Sampling station C1 has the lowest turbidity $(32.37 \pm 5.15 \mathrm{NTU})$ that can be attributed to clean water due to filtering efficiency of Nyalenda swamp (Figure 2). Sampling station C5 has highest turbidity $(122.98 \pm 18.97$ NTU) due to lots of discharge of untreated wastes from sewerage, industries and Obunga slum around sampling stations C2, C3 and C4. Based on ANOVA test, turbidity shows no significant difference $(\mathrm{p}=0.126>0.05)$ within all the sampling stations. Turbidity of the river water depends on the growth, distribution, stratification and types of hydrophytes; number of inlets and outlets; sediment load due to soil erosion, runoff and impact of wind velocity; re-suspended sediments from the bottom, quantity and quality of discharged wastes, decomposition of organic matter; emergence \& submergence of wetland and also on the seral stage(s) during hydrosere.

\section{Chemical parameters}

Mean monthly values of alkalinity are $107.23 \pm 20.37 \mathrm{mg} / \mathrm{l} ; 124.33$ $\pm 26.52 \mathrm{mg} / \mathrm{l} ; 199.67 \pm 28.93 \mathrm{mg} / \mathrm{l} ; 173.00 \pm 29.58 \mathrm{mg} / \mathrm{l} ;$ and $150.00 \pm$ $28.18 \mathrm{mg} / \mathrm{l}$ at C1, C2, C3, C4 and C5 sampling stations respectively. Levels of alkalinity fluctuate between $107.23 \pm 20.37 \mathrm{mg} / \mathrm{l}$ and $199.67 \pm$ $28.93 \mathrm{mg} / \mathrm{l}$ at sampling station $\mathrm{C} 1$ and C3 respectively but average value of alkalinity of all the five sampling stations is $150.85 \pm 28.23$. ANOVA test revealed that mean $\mathrm{p}$-value of alkalinity is significantly different $(p=0.001 \leq 0.05)$. Alkalinity levels depend on the concentration of dissolved carbonates, bicarbonates and hydroxyl ions present in water due to death \& decay of aquatic flora and fauna, amount of carbon dioxide present in river water, types of paternal rocks at the basement, and on the total area of river under human activities. Higher alkalinity level at sampling station C3 is due to slow water flow rate, continuous contact with parental $\operatorname{rock}(\mathrm{s})$, mechanical and chemical weathering; discharge from soap industry, fish processing and sewerage. Alkalinity level at sampling station $\mathrm{C} 5$ is lower than sampling station $\mathrm{C} 4$ due to absorption of nutrients by excessive vegetative cover of Eichhornia crassipes, growth of planktonic diatoms and other species of macro hydrophytes.

Mean monthly total nitrogen levels are between $400.77 \pm 124.50 \mu \mathrm{g} / \mathrm{l}$ and $857.88 \pm 363.96 \mu \mathrm{g} / \mathrm{l}$ at sampling stations $\mathrm{C} 1$ and $\mathrm{C} 5$ respectively and the mean monthly minimum and maximum values of total phosphorus are $342.17 \pm 112.48 \mu \mathrm{g} / \mathrm{l}$ and $1227.38 \pm 424.28 \mu \mathrm{g} / \mathrm{l}$ respectively. Average values of total nitrogen and phosphorus are $657.27 \pm 227.56 \mu \mathrm{g} / 1$ and $677.18 \pm 20.87 \mu \mathrm{g} / 1$ respectively. ANOVA test shows no significant difference between the values of total nitrogen $(\mathrm{p}=0.418>0.05)$ and total phosphorus ( $\mathrm{p}=0.419>0.05)$. High variations in total nitrogen and total phosphorus concentrations are due to the impacts of domestic animals, industrial waste disposal from slaughter houses, detergents, fish processing, sewage disposal, accumulation of organic matter, death and decay of organisms during succession within the water body, erosion of fertilizers used to maintain golf course and other human activities along River Kisat which originates from Nyalenda swamp and ends in Lake Victoria near the sampling station C5 (Figure 2). Both these nutrient levels of total nitrogen and phosphorus are high in this river due to input of uncontrolled and untreated municipal, industrial waste disposal and accumulation of these nutrients from upstream to down-stream. Monthly average of total phosphorus has decreased at station $\mathrm{C} 5$ because all aquatic organisms absorb phosphorus as micronutrient from the river water. Other researchers have studied macroinvertebrate assemblages as biological indicators of water quality [24], phytoplankton community structure [25] and concluded that the domestic wastes, industrial inputs, agricultural runoff and sewage disposal are the main causes of high nutrient levels in surface waters $[24,25]$, rainfall frequency, livestock, anthropogenic activities, and destruction of vegetation at the catchments are the main reasons of poor water quality [26]

Silicate concentration varies between $3.8 \pm 0.37 \mathrm{mg} / \mathrm{l}$ and $4.46 \pm$ $1.02 \mathrm{mg} / \mathrm{l}$ at sampling stations C5 and C3 respectively along river Kisat. The mean monthly values for silicate do not have much difference from the station $\mathrm{C} 1$ up to the point of discharge C5 into Lake Victoria Basin (Table 1). Using ANOVA test, p-value of silicate shows significant difference $(\mathrm{p}=0.004 \leq 0.05)$ among all the five $\mathrm{C} 1$ to $\mathrm{C} 5$ sampling stations. The highest value of silicate is at sampling station C3 due to the impacts of anthropogenic activities along the river. Before the river ends/drops in Lake Victoria, the last sampling station C5 has the 
Citation: Manohar S, Otieno AA, Kitur EL (2017) Planktonic Diatoms Species Composition and Water Characteristics Along Selected Sites of River Kisat, Kisumu County, Kenya. J Environ Anal Toxicol 7: 475. doi: 10.4172/2161-0525.1000475

Page 5 of 7

\begin{tabular}{|c|c|c|c|c|c|c|c|}
\hline & \multirow[b]{2}{*}{$\mathrm{C} 1$} & \multirow[b]{2}{*}{$\mathrm{C2}$} & \multicolumn{2}{|c|}{ Sampling stations } & \multirow[b]{2}{*}{ C5 } & \multirow[b]{2}{*}{ Average values } & \multirow[b]{2}{*}{$\begin{array}{c}p \text {-value } \\
(p \leq 0.05)\end{array}$} \\
\hline & & & C3 & C4 & & & \\
\hline \multicolumn{8}{|l|}{ Physical parameters } \\
\hline Temperature $\left({ }^{\circ} \mathrm{C}\right)$ & $25.07 \pm 0.78$ & $24.78 \pm 0.67$ & $24.95 \pm 0.71$ & $24.75 \pm 0.54$ & $24.63 \pm 0.42$ & $24.84 \pm 0.65$ & $P=0.441$ \\
\hline Flow rate $(\mathrm{Km} / \mathrm{h})$ & $1.4 \pm 0.05$ & $1.5 \pm 0.05$ & $1.3 \pm 0.01$ & $1.7 \pm 0.08$ & $1.00 \pm 0.02$ & $1.38 \pm 0.05$ & $P=0.358$ \\
\hline $\mathrm{pH}$ & $6.12 \pm 0.16$ & $7.69 \pm 0.17$ & $8.97 \pm 0.22$ & $8.85 \pm 0.24$ & $7.72 \pm 0.24$ & $7.87 \pm 0.24$ & $p=0.001$ \\
\hline Dissolved oxygen (mg/l) & $5.92 \pm 0.75$ & $4.11 \pm 0.71$ & $3.8 \pm 0.69$ & $3.69 \pm 0.42$ & $3.42 \pm 0.40$ & $4.19 \pm 0.7$ & $P=0.001$ \\
\hline Conductivity $(\mu \mathrm{S} / \mathrm{cm})$ & $390.75 \pm 118.40$ & $839.65 \pm 323.01$ & $796.45 \pm 253.32$ & $840.93 \pm 330.32$ & $695.43 \pm 330.32$ & $657.27 \pm 186.78$ & $P=0.267$ \\
\hline Turbidity (NTU) & $32.37 \pm 5.15$ & $97.78 \pm 17.11$ & $108.35 \pm 21.55$ & $88.00 \pm 8.85$ & $122.98 \pm 18.97$ & $89.90 \pm 9.76$ & $P=0.126$ \\
\hline \multicolumn{8}{|c|}{ Chemical parameters } \\
\hline Alkalinity (mg/l) & $107.23 \pm 20.37$ & $124.33 \pm 26.52$ & $199.67 \pm 28.93$ & $173.00 \pm 29.58$ & $150.00 \pm 28.18$ & $150.85 \pm 28.23$ & $P=0.001$ \\
\hline Total nitrogen $(\mu \mathrm{g} / \mathrm{l})$ & $400.77 \pm 124.50$ & $629.71 \pm 185.14$ & $720.87 \pm 289.87$ & $677.14 \pm 208.78$ & $857.88 \pm 363.96$ & $657.27 \pm 227.56$ & $P=0.418$ \\
\hline Total phosphorus $(\mu \mathrm{g} / \mathrm{l})$ & $342.17 \pm 112.48$ & $670.16 \pm 122.81$ & $1027.24 \pm 346.31$ & $1227.38 \pm 424.28$ & $1160.77 \pm 361.48$ & $677.18 \pm 20.87$ & $P=0.419$ \\
\hline Silicate $(\mathrm{mg} / \mathrm{l})$ & $4.12 \pm 0.65$ & $4.14 \pm 0.75$ & $4.46 \pm 1.02$ & $4.05 \pm 0.54$ & $3.8 \pm 0.37$ & $4.11 \pm 0.52$ & $P=0.004$ \\
\hline Chlorophyll-a (mg/l) & $95.82 \pm 21.15$ & $105.86 \pm 24.59$ & $113.98 \pm 33.46$ & $123.88 \pm 35.15$ & $213.14 \pm 74.30$ & $130.54 \pm 40.15$ & $P=0.455$ \\
\hline
\end{tabular}

Table 1: Mean monthly values of physico-chemical parameters of river Kisat water collected from five sampling stations (C1 to C5) during the study period (March to August 2016).

lowest silicate value $3.8 \pm 0.37 \mathrm{mg} / \mathrm{l}$ because silica is used by the species of diatoms, absorbed by free floating angiosperms, submerged algal species, and also by other aquatic organisms.

Chlorophyll-a levels fluctuate between $95.82 \pm 21.15 \mathrm{mg} / \mathrm{l}$ and $213.14 \pm 74.30 \mathrm{mg} / \mathrm{l}$ among all the five sampling stations respectively. An average value of Chlorophyll- $a$ is $130.54 \pm 40.15 \mathrm{mg} / \mathrm{l}$ of collected planktonic species. Mean monthly values of Chlorophyll- $a$ are $95.82 \pm$ $21.15 \mathrm{mg} / \mathrm{l}, 105.86 \pm 24.59 \mathrm{mg} / \mathrm{l}, 113.98 \pm 33.46 \mathrm{mg} / \mathrm{l}, 123.88 \pm 35.15 \mathrm{mg} / \mathrm{l}$ and $213.14 \pm 74.30 \mathrm{mg} / \mathrm{l}$ of collected planktonic diatoms from sampling stations C1, C2, C3, C4 and C5 respectively (Table 1). There is gradual increase in the levels of chlorophyll-a from $1^{\text {st }}$ sampling station $\mathrm{C} 1$ to C5 at downstream. These variations are due to the frequency, density and coverage/cover of planktonic species present within this river.

All the mean monthly values of $\mathrm{pH}$, conductivity, turbidity, total nitrogen and total phosphorus are higher than the recommended local and International Standards of water quality according to NEMA and WHO $[27,28]$ respectively.

\section{Species composition of planktonic diatoms}

There are 13 genus belonging to a single family Bacillariophyceae and composed of total 26 species of planktonic diatoms which were collected, identified and recorded (Table 1). Species composition of planktonic diatoms are $21,15,17,18$ and 20 within the sampling stations $\mathrm{C} 1, \mathrm{C} 2, \mathrm{C} 3, \mathrm{C} 4$ and $\mathrm{C} 5$ respectively during the study period. Only genus Nitzschia was recorded with its five species but four species of Nitzschia are present in all (C1 to $\mathrm{C} 5)$ sampling stations except $N$. dessippata which is absent in sampling station C3. Another genus Aulacoseira consists three species but A. ambigua is absent in $\mathrm{C} 2$ and $A$. nyassensis is absent in C3 but A. schroidera is absent in C3, C4 and C5. There are seven genus which are Amphora, Cyclotella; Cymbella; Diatoma; Fragillaria; Navicula and Synedra have only two species each, while these four genus Gomphocymbella, Pinnularia, Stephomodiscus, and Surillella are with only one species each. Planktonic diatom species has its own range of physico-chemical characteristics within the waterbody due to the impacts of surrounding environment and anthropogenic activities. Presence or absence of any planktonic diatom or their species composition in each sampling station is directly influenced by the water quality within the habitats.

Species with $100 \%$ frequency belong to four genus composed of eight species: Cymbella cistula, Cymbella sp, Diatoma hiemiale, Navicula granatum, Nitzschia lucastris, N.palea, N.recta and N.sub-acicularis, are present in all sampling stations C1 to C5 (Table 2) in water of very slow flowing shallow river with high tolerance range of mean monthly levels of $\mathrm{pH}$ (6.12-8.97), dissolved oxygen (3.42-5.92 mg/l); conductivity (390.75-840.93 $\mu \mathrm{S} / \mathrm{cm})$; turbidity (32.37-122.98 NTU); alkalinity (107.23-199.67mg/l); total nitrogen (400.77-857.88 $\mu \mathrm{g} / 1)$; total phosphorus (342.17-1227.38 $\mu \mathrm{g} / 1)$ and silicate $(3.8-4.46 \mathrm{mg} / 1)$, (Table 1).

Species with $80 \%$ frequency belong to five genus composed of six species which are Aulacoseira ambigua, A.nyassensis; Cyclotella kutzinghiana, Navicula sp; Nitzschia dessippata and Surillella ovalis. One of the species of the genus Navicula is absent in C4 sampling station due to very high total phosphorus $(1227.38 \mu \mathrm{g} / 1)$ and high conductivity $(840.93 \mu \mathrm{S} / \mathrm{cm})$ levels. Aulacoseira ambigua is absent in C2 due to the seways from the slum. Four species: A. nyassensis, Cyclotella kutzinghiana, Nitzschia dessippata, Surillella ovalis which are absent in C3 sampling station due to high $\mathrm{pH}(8.97)$ and alkalinity $(199.67 \mathrm{mg} / \mathrm{l})$ levels because untreated sewage is discharged in the river before sampling station C3 (Figure 2).

Species with $60 \%$ frequency are Amphora sp, Diatoma elongatum, Fragillaria aethiopica, Stephomodiscus astraca, and Synedra cunningtonii. Out of these five species only three species Amphora sp, Diatoma elongatum and Fragillaria aethiopica are absent in C2 and C4 due to high conductivity $(840.93 \mu \mathrm{S} / \mathrm{cm})$. Stephomodiscus astraca is absent in $C 3$ and $C 5$ due to high turbidity (108.35 to $122.98 \mathrm{NTU}$ ) and high total nitrogen $(720.87$ to $857.88 \mu \mathrm{g} / 1)$ but Synedra cunningtonii is absent in $\mathrm{C} 1$ and $\mathrm{C} 2$ due to low alkalinity.

Planktonic diatom species with $60 \%$ frequency are:Amphora $s p$, Diatoma elongatum, Fragillaria aethiopica, Stephomodiscus astraca, and Synedra cunningtonii. Out of these five species, only three species: Amphora sp, Diatoma elongatum and Fragillaria aethiopica are absent in 
Citation: Manohar S, Otieno AA, Kitur EL (2017) Planktonic Diatoms Species Composition and Water Characteristics Along Selected Sites of River Kisat, Kisumu County, Kenya. J Environ Anal Toxicol 7: 475. doi: 10.4172/2161-0525.1000475

Page 6 of 7

\begin{tabular}{|c|c|c|c|c|c|c|c|}
\hline Genus & Species & c1 & $\mathrm{C} 2_{2}$ & $c_{3}$ & C4 & C5 & Frequency (\%) \\
\hline \multirow{2}{*}{ 1. Amphora } & (i) Amphora ovaris & $(+)$ & $(-)$ & $(+)$ & $(-)$ & $(-)$ & 40 \\
\hline & (ii) Amphora sp & $(+)$ & $(-)$ & $(+)$ & $(-)$ & $(+)$ & 60 \\
\hline \multirow[t]{3}{*}{ 2. Aulacoseira } & (i) Aulacoseira ambigua & $(+)$ & $(-)$ & $(+)$ & $(+)$ & $(+)$ & 80 \\
\hline & (ii) Aulacoseira nyassensis & $(+)$ & $(+)$ & $(-)$ & $(+)$ & $(+)$ & 80 \\
\hline & (iii) Aulacoseira schroidera & $(+)$ & $(+)$ & $(-)$ & $(-)$ & $(-)$ & 40 \\
\hline \multirow[t]{2}{*}{ 3. Cyclotella } & (i) Cyclotella ocellata & $(-)$ & $(-)$ & $(+)$ & $(-)$ & $(+)$ & 40 \\
\hline & (ii) Cyclotella kutzinghiana & $(+)$ & $(+)$ & $(-)$ & $(+)$ & $(+)$ & 80 \\
\hline \multirow[t]{2}{*}{ 4. Cymbella } & (i) Cymbella cistula & $(+)$ & $(+)$ & $(+)$ & $(+)$ & $(+)$ & 100 \\
\hline & (ii) Cymbella sp & $(+)$ & $(+)$ & $(+)$ & $(+)$ & $(+)$ & 100 \\
\hline \multirow[t]{2}{*}{ 5. Diatoma } & (i) Diatoma elongatum & $(+)$ & $(-)$ & $(+)$ & $(-)$ & $(+)$ & 60 \\
\hline & (ii) Diatoma hiemiale & $(+)$ & $(+)$ & $(+)$ & $(+)$ & $(+)$ & 100 \\
\hline \multirow[t]{2}{*}{ 6. Fragillaria } & (i) Fragillaria aethiopica & $(+)$ & $(-)$ & $(+)$ & $(-)$ & $(+)$ & 60 \\
\hline & (ii) Fragillaria longissimi & $(-)$ & $(-)$ & $(-)$ & $(+)$ & $(-)$ & 10 \\
\hline \multirow{3}{*}{$\begin{array}{l}\text { 7. Gomphocymbella } \\
\text { 8. Navicula }\end{array}$} & (i) Gomphocymbella beccari & $(-)$ & $(-)$ & $(-)$ & $(-)$ & $(+)$ & 10 \\
\hline & (ii) Navicula sp & $(+)$ & $(+)$ & $(+)$ & $(-)$ & $(+)$ & 80 \\
\hline & (ii) Navicula granatum & $(+)$ & $(+)$ & $(+)$ & $(+)$ & $(+)$ & 100 \\
\hline \multirow[t]{5}{*}{ 9. Nitzschia } & (i) Nitzschia dessippata & $(+)$ & $(+)$ & $(-)$ & $(+)$ & $(+)$ & 80 \\
\hline & (ii) Nitzschia lucastris & $(+)$ & $(+)$ & $(+)$ & $(+)$ & $(+)$ & 100 \\
\hline & (iii) Nitzschia palea & $(+)$ & $(+)$ & $(+)$ & $(+)$ & $(+)$ & 100 \\
\hline & (iv) Nitzchia recta & $(+)$ & $(+)$ & $(+)$ & $(+)$ & $(+)$ & 100 \\
\hline & (v) Nitzschia sub-acicularis & $(+)$ & $(+)$ & $(+)$ & $(+)$ & $(+)$ & 100 \\
\hline 10. Pinnularia & (i) Pinnularia viridis & $(-)$ & $(-)$ & $(+)$ & $(+)$ & $(-)$ & 40 \\
\hline 11. Stephomodiscus & (i) Stephomodiscus astraca & $(+)$ & $(+)$ & $(-)$ & $(+)$ & $(-)$ & 60 \\
\hline 12. Surillella & (i) Surillella ovalis & $(+)$ & $(+)$ & $(-)$ & $(+)$ & $(+)$ & 80 \\
\hline \multirow[t]{3}{*}{ 13. Synedra } & (i) Synedra cunningtonii & $(-)$ & $(-)$ & $(+)$ & $(+)$ & $(+)$ & 60 \\
\hline & (ii) Synedra ulna & $(+)$ & $(-)$ & $(-)$ & $(+)$ & $(-)$ & 40 \\
\hline & Number of planktonic species present & 21 & 15 & 17 & 18 & 20 & \\
\hline
\end{tabular}

Key: (+) Present, (-) Absent; Frequency: 100\%-Dark green, 80\%-Light green, 60\%-Brown, 40\%-Purple, 10\%-Yellow.

Table 2: Genus and their species composition of planktonic diatoms collected from five selected sampling stations (C1 to C5) along River Kisat (March to August 2016).

$\mathrm{C} 2$ and $\mathrm{C} 4$ due to high conductivity and total nitrogen. Stephomodiscus astraca is absent in C3 and C5 due to high turbidity (108.35 to 122.98 NTU) and high total nitrogen (720.87 to $857.88 \mu \mathrm{g} / 1)$ but Synedra cunningtonii is absent in $\mathrm{C} 1$ and $\mathrm{C} 2$ sampling stations due to low alkalinity and low level of total phosphorus but this Synedra cunningtonii planktonic diatom is present in sampling stations C3, C4 and C5 due to its preferable levels of high alkalinity $(150.00-199.67 \mathrm{mg} / 1)$, total nitrogen (677.14-857.88 $\mu \mathrm{g} / 1)$ and total phosphorus (1027.24-1227.38 $\mu \mathrm{g} / 1$ ) are suitable for its growth (Tables 1 and 2).

Species with $40 \%$ frequency are:Amphora ovalis, Aulacoseira schroidera, Cyclotella ocellata, Pinnularia viridis, and Synedra ulna (Table 2). These planktonic diatom species are adopted in its own range of physico-chemical characteristics. Amphora ovalis is present in C1 and C3 due to its wide range of adaptation of conductivity (390.75$796.45 \mu \mathrm{S} / \mathrm{cm}$ ), low dissolved oxygen (3.8-5.92 mg/l), $\mathrm{pH}$ (6.12- 8.97), total nitrogen $(400.77-720.87 \mu \mathrm{g} / 1)$ and total phosphorus (342.17$1027.24 \mu \mathrm{g} / 1$ ). Aulacoseira schroidera present in sampling stations (C1 \& C2) within wide range of conductivity, turbidity (32.37-97.78NTU), alkalinity (107.23-124.33 mg/1), total nitrogen (400.77-629.71 $\mu \mathrm{g} / 1)$ and total phosphorus (342.17-670.16 $\mu \mathrm{g} / 1)$ levels. Cyclotella ocellata present in C3 \& C5 sampling stations and adopted within the range of low dissolved oxygen (3.42-3.8 mg/l), conductivity (695.43-796.45 $\mu \mathrm{S} / \mathrm{cm})$, high alkalinity (150.0-199.67 $\mathrm{mg} / \mathrm{l})$, high total nitrogen (720.87-857.88 $\mu \mathrm{g} / 1)$, total phosphorus (1027.24-1160.77 $\mu \mathrm{g} / 1$ ) and silicate (3.8-4.46 mg/l). Pinnularia viridis present in C3 \& C4 sampling stations within $\mathrm{pH}$ (8.85-8.97), low dissolved oxygen, high conductivity (796.45-840.93 $\mu \mathrm{S} / \mathrm{cm})$, high alkalinity $(173.00-199.67 \mathrm{mg} / \mathrm{l})$ and total phosphorus (1027.24-1227.38 $\mu \mathrm{g} / 1)$ levels. Synedra ulna is present in $\mathrm{C} 1$ and $\mathrm{C} 4$ sampling stations within the range of high $\mathrm{pH}(6.12-8.85)$, low oxygen (3.69-5.92 mg/l), conductivity (390.75-840.93 $\mu \mathrm{S} / \mathrm{cm})$, turbidity (32.37-88.00 NTU), alkalinity $107.23-173.00 \mathrm{mg} / \mathrm{l})$, total nitrogen (400.77-677.14 $\mu \mathrm{g} / 1)$, total phosphorus (342.17-1227.38 $\mu \mathrm{g} / 1)$ and silicate $(4.05-4.12 \mathrm{mg} / \mathrm{l})$.

Species with $10 \%$ frequency are: Fragillaria longissimi and Gomphocymbella beccari which are exclusively present only once in sampling station $\mathrm{C} 4$ and $\mathrm{C} 5$ respectively. Unique presence of each species indicates that Fragillaria longissimi prefer very high conductivity $(840.93 \mu \mathrm{S} / \mathrm{cm})$ and very high total phosphorus $(1227.38 \mu \mathrm{g} / \mathrm{l})$; while Gomphocymbella beccari prefer very high total nitrogen $(857.88 \mu \mathrm{g} / \mathrm{l})$, very high turbidity (122.98 NTU) and low dissolved oxygen (3.42 mg/l) levels.

Those planktonic diatoms species which are present in the water of river Kisat (Table 2) within the average of $7.87 \mathrm{pH}$, low dissolved oxygen levels with an average of $4.19 \mathrm{mg} / \mathrm{l}$, and high conductivity, turbidity, alkalinity, total nitrogen and phosphorus in all five sampling stations (Table 1) are the indicator(s) of water quality. All these physico-chemical parameters of river water have direct influence on growth, distribution, presence or absence, and composition of plant species. Therefore, planktonic diatoms are useful for the prediction of water quality.

High frequency of planktonic diatoms presence within fresh water bodies in any country is the sign of mismanagement of their wetlands and with time, area or a region may face serious environmental problems which may not support healthy life. Therefore, it is recommended that public awareness and strong enforcement of environmental laws must be practiced to protect these water resources and to maintain healthy aquatic ecosystem(s).

\section{Conclusion}

Planktonic diatom Fragillaria longissimi prefers very high levels of conductivity $(840.93 \mu \mathrm{S} / \mathrm{cm})$ and total phosphorus $(1227.38 \mu \mathrm{g} / \mathrm{l})$ and Gomphocymbella beccari prefers very high levels of total nitrogen $(857.88 \mu \mathrm{g} / \mathrm{l})$ and turbidity (122.98 NTU) but low level of dissolved oxygen $(3.42 \mathrm{mg} / \mathrm{l})$. These species Cymbella cistula, Cymbella $s p$, Diatoma hiemiale, Navicula granatum, Nitzschia lucastris, N.palea, N.recta and N.sub-acicularis are also planktonic diatoms present within wide range of nutrient levels and their composition are the indication of poor water quality of river Kisat. Based on these results, it is concluded that there is strong close link and interaction between planktonic species composition and physico-chemical characteristics of 
Citation: Manohar S, Otieno AA, Kitur EL (2017) Planktonic Diatoms Species Composition and Water Characteristics Along Selected Sites of River Kisat, Kisumu County, Kenya. J Environ Anal Toxicol 7: 475. doi: 10.4172/2161-0525.1000475

the waterbody. Therefore, planktonic diatoms should be considered to be used as one of the best useful indicators to assess the water quality.

\section{References}

1. APHA (1999) Standard Methods for the Examination of Water and Wastewater. American Public Health Association ( $13^{\text {th }}$ Ed), Washington DC.

2. Taylor JC, de la Rey PA, van Rensburg L (2005) Recommendations for the collection, preparation and enumeration of diatoms from riverine habitats for water quality monitoring in South Africa. Afri J Aquat Sci 30: 65-75

3. Ndeda LA, Manohar S (2014) Bio concentration factor and Translocation Ability of Heavy Metals within different Habitats of Hydrophytes in Nairobi Dam, Kenya. IOSR J Environ Sci Toxicol Food Technol (IOSR-JESTFT) 8: 42-45.

4. Manohar S, Kitur EL, Kibet FC (2016) Water Quality and Plant Species Composition of Chemususu Dam, Baringo County, Kenya. J Environ Anal Toxicol 6: 1-6.

5. Madsen JD, Wersal RM (2012) A Review of Aquatic Plant Monitoring and Assessment Methods. Aquatic Ecosystem Restoration Foundation, Marietta, Atlanta.

6. Gulec AK, Yildirim NC, Danabas D, Yildirim N (2011) Some haematological and biochemical parameters in common carp (Cyprinuscarpio L.,1758) in Munzur River, Tunceli, Turkey. Asian J Chem 23: 910-912.

7. Aitkenhead-Peterson JA, Nahar N, Harclerode CL, Stanley NC (2011) Effect of urbanization on surface water chemistry in south-central Texas. Urban Ecosyst 14: $195-210$

8. Ayeni AO, Balogun II, Soneye AS (2011) Seasonal assessment of physicochemical concentration of polluted Urban River: A case of Ala River in South-western-Nigeria. J Environ Sci 5: 21-33.

9. Archibald CG, Taylor JC (2004) The assessment of diffuse pollution from acid mine drainage using an updated and revised diatom assessment procedure as an added value bio-monitoring tool. Water Sci Technol 55: 151-160.

10. Kitur EL (2009) Comparative Study on the Influence of Variations in Environmental Factors on the Phytoplankton Properties of Selected Reservoirs in Central Kenya. Unpublished Ph.D. Thesis, Kenyatta University, Nairobi, Kenya.

11. Ndeda LA, Manohar S (2014) Determination of heavy metals in Nairobi Dam Water, Kenya. IOSR J Environ Sci Toxicol Food Technol (IOSR-JESTFT) 8: 68-73.

12. Otieno AA (2016) Assessment of water quality using planktonic diatoms on River Kisat, Lake Victoria Catchment, Kisumu County, Kenya. Unpublished M.Sc. Thesis, Kenyatta University, Nairobi, Kenya.

13. Dodds WK (2002) Freshwater Ecology: Concepts and Environmental Applications. Academic Press, California 569.
14. Hill BH, Herlihy AT, Kaufmann PR, DeCelles SJ, Vander Borgh MA (2003) Assessment of streams of the eastern United States using a periphyton index of biotic integrity. Ecol Indicators 2: 325-338

15. Torrisi M, Scuri S, Dell'Uomo A, Cocchioni M (2010) Comparative monitoring by means of diatoms, macroinvertebrates and chemical parameters of an Apennine watercourse of central Italy: The River Tenna. Ecol Indicators 10: 910-913.

16. Blinn D, Herbst D (2003) Use of diatoms and soft algae as indicators of environmental determinants in the Lahontan Basin, USA. Annual Report for California State Water Resources Board.

17. Walsh G, Wepener V (2009) The influence of land use on water quality and diatom community structures in urban and agriculturally stressed rivers. Water SA 35: 579-594.

18. Duong TT, Morin S, Coste M, Herlory O, Feurtet-Mazel A, et al. (2010) Experimental toxicity and bioaccumulation of cadmium in freshwater periphytic diatoms in relation with biofilm maturity. Sci Total Environ 408: 552-562.

19. Wetzel RG (2001) Limnology: Lake and River Ecosystems (3rd ed). Academic press, San Diego 1006.

20. Khan FA, Ansari AA (2005) Eutrophication: An Ecological Vision. Bot Rev 71 449-482.

21. Smol JP (2008) Pollution of Lakes and Rivers: A Paleoenvironmental Perspective ( $2^{\text {nd }}$ Edn). Blackwell Publishing Co. Oxford.

22. Fallu MA, Allaire N, Pienitz R (2000) Freshwater Diatoms from Northern Que'bec and Labrador, Canada. Species-Environment Relationships in Lakes of Boreal Forest, Forest Tundra and Tundra Regions. Bibliotheca Diatomologica 45: 200.

23. Lange-Bertalot H (2001) Diatoms of the European Inland Waters and Comparable Habitats. In: Diatoms of Europe (Ed. H. Lange- Bertalot) 526.

24. Masese FO, Muchiri M, Raburu PO (2009) Macroinvertebrate assemblages as biological indicators of water quality in the Moiben River, Kenya. Afr J Aquatic Sci 34: 15-26.

25. Lung'Ayia HB, M'harzi A, Tackx M, Gichuki J, Symoens JJ (2000) Phytoplankton community structure and environment in the Kenyan waters of Lake Victoria. Freshwater Biol 43: 529-543.

26. Mathooko JM (2001) Disturbance of a Kenya Rift Valley stream by daily activities of local people and their livestock. Hydrobiologia 458: 131-139.

27. NEMA (2006) Water quality regulations. National Environment Management Authority, Nairobi, Kenya.

28. WHO (2011) Guideline for drinking water quality (4 ${ }^{\text {th }}$ Ed). World Health Organization, Geneva, Switzerland. 